\title{
Crisis, Innovation and e-Participation: Towards a Framework for Comparative Research
}

\author{
Joachim Åström ${ }^{1}$, Hille Hinsberg ${ }^{2}$, Magnus E. Jonsson ${ }^{3}$, and Martin Karlsson ${ }^{4}$ \\ ${ }^{1}$ Örebro University, Sweden \\ joachim.astrom@oru.se \\ ${ }^{2}$ PRAXIS Center for Policy Studies, Tallinn, Estonia \\ hille.hinsberg@praxis.ee \\ ${ }^{3}$ Research School for Technology Mediated Knowledge Processes, Örebro, Sweden \\ magnus.jonssoneoru.se \\ ${ }^{4}$ Örebro School of Public Affairs, Sweden \\ martin.karlsson@oru.se
}

\begin{abstract}
Why and how do e-participation policies sometimes flow with politics as usual and sometimes lead to challenging powerful elites and institutions? With the aim of investigating this question, we introduce a framework for comparative research that includes not only systemic but also circumstantial factors. The approach is tested in a comparative case study of three northern European countries--Sweden, Estonia and Iceland--that are all experimenting with e-participation but which are experiencing rather different levels of crisis. The results show that innovation and elite challenging aspirations are very much related to the type and degree of crisis. It is therefore argued that the interplay between institutional constraints and circumstantial catalysts needs further scholarly attention and elaboration.
\end{abstract}

Keywords: Democratic Innovation, Crisis, e-Participation, Comparative Research, ICT.

\section{Introduction}

Regardless of all the differences among European democracies, similar challenges regarding a gap between citizens and their governments seem to work as a starting point for democratic renewal initiatives which show remarkable similarities across countries [1]. One intriguing development is the introduction of "democratic innovations", which refers to institutions that have been specifically designed to increase and deepen citizen participation in the political decision-making process, such as different forms of e-participation [2]. In the scholarly debate on these innovations, much attention has been paid on finding successful recipes of design. By following Archon Fung [3], many scholars have argued that the success of democratic innovations and their consequences for democratic governance depend, to a large extent, on "the details of their institutional construction". Empirical research supports this view by showing that the methods by which participants are selected, the timing of consultations within 
the policy cycle, and the mode of communication adopted set a decisive context for participant interaction. Even though not all democratic innovations succeed in engaging citizens, some do, and the odds for success and failure differ considerably according to aspects of design [4].

However, democratic innovations, just as any innovation, are more than ideas and designs; they are ideas in action. Therefore, as Newton aptly points out [5], they depend on implementation, and "good innovations depend on good ideas and designs that can be implemented successfully". But empirical research on the implementation of democratic innovations is still in its infancy, and there is still little knowledge on how similar designs are in fact mediated by various local contexts: how they are translated locally, why they are implemented differently, and what consequences they have on democracy.

Examples of comparative internet political research are growing in numbers, but these have mainly been conducted in the field of electoral politics. Concentrating primarily on European and U.S. case studies, this research has criticized the idea that American innovations in e-campaigning could simply be replicated elsewhere. By accounting for mainly institutional variables such as party structure and funding, electoral regulations, and media systems, research shows how similar instances of e-campaigning are shaped by national contexts $[6,7]$.

When it comes to e-participation, it is local government that is the laboratory for research and experimentation. In most countries, experimentation in e-participation, if there is any, takes place primarily at this level [4]. This focus on local-level experimentation offers researchers some specific advantages and challenges. The closeness of political actors makes the effects of new processes more readily observable to those who govern localities - and to researchers - than to those at higher levels of governance. Furthermore, the large number of local governments is advantageous when it comes to generalizing results [8]. However, local government vary across countries on multiple dimensions (i.e., its purpose; its autonomy and relationship to other levels of government; its relationship to its residents; its structure, form and setting; and its politics and policy), which is challenging [9]. As a consequence of this complexity, there is a general lack of systematic comparison on local politics across countries. This is not only the case in the field of e-participation. Urbanists in general, Pierre [10, p. 446] states, "have been surprisingly slow in using comparison as a research strategy", and according to Wolman [9, p. 88], the main threshold problem is "the lack of a common framework to conduct such research, to place results, and build upon them".

The general aim of this paper is to help remedy this research gap by exploring what constitutes the "context" that surrounds and influences the implementation of eparticipation at the local government level. The specific question we set out to explain is why and how e-participation policies sometimes flow with politics as usual and sometimes lead to challenging powerful elites and institutions. While "elitechallenging" or "citizen-centric" forms of participation reflect a critical citizenry whose members want to put incumbent authorities under pressure to respond to their demands [11], and while they tend to have a positive impact on democracy [12], they are still rare exceptions $[13,14]$. 
To grasp a better understanding of why, when and how these rare exceptions occur, we will start by proposing a new approach to comparative research, based on a wider, more flexible understanding of "context" that accounts for the interplay between institutional constraints and circumstantial catalysts [6]. This framework is subsequently used in order to compare e-participation implementation in Sweden, Estonia and Iceland, three northern European countries that are all experimenting with e-participation but are experiencing rather different levels of crises. While different "systemic elements" come to the fore in the implementation of e-participation depending on the political system, circumstantial factors--or different degrees of crises--transcend boundaries and thus provide an interesting starting point for empirical analysis. Information about the three cases is based on a series of personal interviews conducted with local politicians and civil servants in Sweden, Estonia and Iceland during the spring 2012, as well as a joint workshop with participants from all three countries in the autumn 2012. Additionally, we have used evaluations and case-reports from respective countries (our own and others) as well as public data.

\section{$2 \quad$ What Context Matters for e-Participation?}

Encouraged by Trevisian and Oates [6], this study will thus introduce a broader framework that accounts for the interplay between institutional constraints and circumstantial catalysts in the implementation of e-participation. Following the footsteps of previous comparative local government research, we will particularly analyze the local government system, or central-local relations, as well as the character of local democracy. When it comes to circumstantial factors, we will separate between the nature of policy-problems on the one hand and the political climate on the other. In combination, these elements are expected to be key factors influencing the degree of innovation in the implementation of e-participation. Innovation is usually seen as offering an opportunity to change the rules of the game, which is more motivating in situations characterized by crises. However, this is seldom recognized in theoretical frameworks in comparative digital research. Instead, "context" is usually narrowed down to different institutional constraints.

\section{$2.1 \quad$ Sweden}

Systemic Factors. The Swedish political system is first and foremost characterized by a strong position of political parties. Every elected politician represents a political party, and Swedish elections are centered on parties rather than individual candidates. Also, political participation in Sweden has traditionally been channeled through political parties and popular mass movements, fostering a collectivist ideal for citizen participation and democratic citizenship. In a recent comparative analysis of sixteen European countries, investigating the extent to which local democratic institutions and political cultures are "party democratic" or "citizen democratic", Sweden is found to be the most "party democratic" political system [15, p. 9].

The Swedish system is also based on strong local government with far-reaching autonomy [16, p. 233]. Local governments raise the majority of the income taxes from 
the population and have gained the responsibility for a growing number of welfare services (from national as well as county governments) during the last fifty years [16, p. 236]. The local government sector is also a large employer that occupies around $20 \%$ of the Swedish workforce.

Swedish citizens are usually considered relatively informed about politics [17], and turnout in elections is comparatively high (approximately $80 \%$ of the electorate vote in local authority, county council and national elections) [18].

Circumstantial Factors. During the last decades, there has been a growing debate over the state of democracy in Sweden. As in many other European countries, the Swedish public is becoming more dissatisfied with the traditional institutions of representative democracy and with conventional forms of participation [19, 20]. A notable strengthening of the socio-economic status in the country has resulted in a change towards individualization among its citizens. In recent comparative studies, Swedes are found among the most individualized citizens in the world [12]. As a result of this transformation, the strong collectivistic tradition of political engagement in the country has been questioned. The formerly strong mass popular movements, including the political parties, have lost a large share of their members. A widespread decline in political trust and party membership as well as party identification has caused some scholars to claim that political parties are losing their legitimacy [21, 20].

However, the contemporary political situation is still one of stability. Sweden has not been directly involved in a war since 1809 and is, along with Canada, the only state rewriting its constitution despite the absence of a political crisis [22]. The country has managed through the current economic crises better than most other European countries, and the parliamentary situation is still characterized by pragmatism, coalition-building and striving for consensus. While turnout and levels of trust are going down, they are still at a relative high from a comparative perspective.

e-Participation Implementation. In attempts to mend the apparent challenges of Swedish representative democracy, a trend of introducing new forms of citizen participation (e.g., e-participation initiatives) has nonetheless emerged [23]. In line with the Swedish tradition of strong local governments, the vast majority of these participatory initiatives have been implemented at the local level, championed by local governments. However, local e-participation initiatives are still rather few and unevenly diffused among Swedish local governments. The local governments that have implemented e-participation initiatives are often characterized by relatively low electoral participation as well as relatively weak political trust among citizens. Case studies report that local politicians often view e-participation initiatives as a potential remedy for these challenges [24]; [25], which indicates a link between circumstantial factors and e-participation initiatives. However, it soon becomes evident that the catalyst for change is not very strong. First, the initiatives are implemented as potential remedies for a declining trust in political parties and institutions, but not as a process for solving specific policy problems. One illustrative example is the online referendums in the municipality of Sigtuna. The local government decided to implement a large number of local referendums in order to spire greater political participation and foster political trust, but the policy issues for these referendums were chosen at a later stage and were not the main focus of the participatory process. Second, the new arenas of 
engagement have often been detached from the traditional party arena of representative democracy. Local governments are locked into old structures and ways of working, only with islands of participatory practice [cf. 26, 27].

\subsection{Estonia}

Systemic Factors. Since the restoration of independence in 1991, Estonia has built and developed a democratic structure. Practically starting from scratch after the occupation of the Soviet Union, all the functions and apparatus of a modern state, including a legal code, a civil service, and national and sub-national institutions have been built up. Today, Estonia is a Parliamentary Republic. The political parties are the main instrument of channeling power from the citizens, and the general elections are the central mechanisms that give the people influence over policy-making. Another important trait of the Estonian political system is central authority. This is partly due to the fact that the "cornerstone of Estonian local governance-the municipality — was abolished by the Soviet regime" [28, p. 168]. The local authorities are thus formally autonomous in acting within the framework on fiscal and normative matters, but the framework has "not been conducive to actual autonomy and, hence, the development of local democracy" [28, p. 190]. Due to the regulations of tax collection and private enterprise in social services, the revenues for local governments are low. Therefore, the possibility for local governmental maneuvers is low.

Circumstantial Factors. The political parties dominate Estonian political life, yet they do not enjoy high public trust, with around $40 \%$ of the citizens claiming they would not vote for any of the competing parties in an election [29]. The public distrust was recently manifested in a much-publicized debate article in November 2012, in which the Charter 12 was presented. The article was published in connection with a political scandal concerning party financing, with the explicit message that "Estonia's democracy is crumbling before our eyes", and "democratic legitimation [sic] has ceased" [30]. The Charter did catch both the public (17,000 supported The Charter in an online process) and the President's interest (who supported the call). The Charter then became the platform for an online political process, leading to the creation of the site The Peoples Assemble, 'Rahvakogu', was ended with a "Deliberation Day" in April 2013. The political climate can thus be said to be characterized by instability and low trust towards the political establishment. The policy problems facing Estonia are, despite the current Charter 12 events, of a resource character. The political parties are currently under pressure and scrutiny and do, in general, receive low trust.

e-Participation Implementation. With a diffusion of approximately $75 \%$ of the population, Estonia is among the top 30 states in the world when it comes to internet access. Already early on in the process of democratization, the Estonian government turned to ICT solutions to enhance citizen participation. The earliest and most notable actions were the introduction of the TOM (Today I Decide) system in 2001, the introduction of e-voting in 2005 and the osale.ee platform in 2007. Due to the nationallevel crisis and the creation of the "People's Assembly" platform in 2013, Estonia gained its first elite-challenging e-participation process. The process was initiated by 
the President and shaped in co-operation with the civil society. Aimed to invite lay citizens to discuss and propose fundamental changes in the party structure, the initiative must be viewed as rather radical.

On the local level, however, e-participation tools have been developing at a considerably slower pace than those created by the central government or citizen initiatives. For example, the VOLIS system is an online decision-making system for local councils, and the application aims to integrate e-governance, participatory democracy, and records management. It is in some sense similar to the TOM system, offering possibilities for citizens to propose issues to the council for discussion or adoption and to collect supporting signatures. However, the system has not been widely adopted. The basic reason for this is the centralized institutional framework and the additional costs brought on the municipalities and regions interested in the system.

\subsection{Iceland}

Systemic Factors. Despite Iceland's long tradition of democracy with the first parliament, the Althing (Alpingi), established as early as $930 \mathrm{CE}$, the modern democratic state took shape after its independence from Denmark in 1944, when Iceland constituted itself as a semi-presidential republic with parliamentary rule. Iceland is a decentralized state with strong local democratic traditions. Municipalities as a political unit date back to the first "free men" that conquered Iceland in $800 \mathrm{CE}$. Iceland consists of 75 municipalities, which, with a total population of 320,000 citizens, makes a "great number of small, sparsely populated municipalities" [31, p. 21].

With its structure as a unitary state, the national government of Iceland rules the state, while the local authorities, with restrictions from the national level, rule the municipalities. Tax revenue is collected by the municipalities, and thus a huge part of the welfare services is provided by the municipality. The municipalities are, therefore, under the law, entitled to maneuver within the frames of their budgets.

Circumstantial Factors. The contemporary Icelandic political context can be characterized as being in a stable post-crisis condition, after the economic and political crisis that began in the wake of the global financial crisis in 2008. In the aftermath of the financial and political crisis, the sitting government was toppled in 2009. A public discussion on the fundamentals of the Icelandic political system took form. One of the main issues was the drafting of a new constitution. The constitution was drafted online in a crowd-sourcing process, which is unique in its kind.

Iceland has traditionally been considered of good democratic health, with high turnout levels in parliamentary elections (e.g., 85.1\% in 2009) and relatively high turnouts in presidential elections (e.g., 69.3\% in 2012). Parallel to this high level of participation, Icelanders are dissatisfied with the political establishment, a visible trend in that political parties attract fewer members. Some scholars argue that the "political parties in Iceland have become almost empty shells" [32].

The recent developments (i.e., the financial and political crisis), in combination with a notion that the political parties resemble "empty shells", have affected the levels of general trust in politics in Iceland. In a poll conducted in 2011, only one in ten 
Icelanders expressed "great trust" in parliament [33]. The political climate is thus characterized by low trust. The policy problems in Iceland concern fundamental political issues. The crisis did affect all political and societal institutions, and it must therefore be considered of fundamental character.

e-Participation Implementation. Early on, Iceland's government was positive to ICT solutions. Already in 1996, the prime minister announced, "The chief objective is that Iceland shall be in the forefront of the world's nations in the utilization of information technology in the service of improved human existence and increased prosperity" [3]. But despite the infrastructure and governmental rhetoric, the rate of democratic innovation and e-participation was low in Iceland until 2008, both on local and national levels. Only a few examples of e-participation innovations could be found on the local level, as, for example, the e-voting referendum in 2001 on whether or not to move the national airport located in Reykjavik as well as a deliberative online project concerning the "Local Agenda 21" policy in 2004 [35].

After the crisis in 2008, the rate of e-participatory innovation rose and became ever more elite-challenging. The first and most prominent example on the national level was the process of drafting the new constitution, while the most prominent example on the local level was the launch and implementation of the Better Reykjavik system. The process of drafting the new constitution began with the National Forum in 2010 in which a decision was taken that a citizen assembly, the "Constitutional Council", should be elected by popular vote. The Constitutional Council then chose to put the process online, and the drafting of the constitution soon metamorphosed into an online process that invited every citizen of Iceland to participate in the writing of the new constitution [36]. Social media platforms used were YouTube, Twitter, Facebook and Flickr. A first draft of the new constitution was handed over to parliament in July 2011, and an advisory referendum was held in October 2012. The drafting is thus still in progress. On a local level, the Better Reykjavik system was implemented by the new local party, the Best Party, in co-operation with the non-profit organization Citizen Foundation. The system allows citizens of Reykjavik to participate by posting, discussing and voting upon citizen initiatives.

\section{Comparative Analysis}

At first glance, Sweden, Estonia and Iceland share many similarities in relation to eparticipation. All three countries are characterized by strong ICT-infrastructure and high levels of ICT-modernization among its populations. However, the e-participation initiatives implemented in these countries differ widely in terms of innovation and elite challenging aspirations. How can these differences be understood in relation to the interplay between circumstantial and systemic factors?

In the Swedish case, e-participation initiatives are primarily implemented at the local level and are seldom initiated to handle specific policy problems. Rather, these initiatives are used as a tool among many to foster citizen participation and political trust in the light of a declining trend in electoral participation and political trust (although from comparably high levels). The degree of pervasiveness and innovation is low in comparison to the other cases, which might be understood in relation to systemic (party-centric) as well as circumstantial (stability) factors. In a comparably 
stable political climate, without any imminent policy problems, e-participation initiatives have not been implemented so as to challenge the party-centric style of policy making. Despite the use of some interesting tools such as e-referendums, online discussion forums, e-panels and e-petitioning, implementation pretty much speaks in favour of "politics as usual".

By comparison, the Estonian case is interesting, since the country is beginning to move beyond the elites' comfort zone. While the Estonian local governments do not have the capacity for innovative e-participation implementation, the country was early in developing a national e-participation platform. The government thus "paved the way" for innovation by constructing a physical and cultural infrastructure for eparticipation early on. However, it was not until the emergence of a legitimacy crisis that a more elite-challenging practice developed with the creation of the "Rahvakogu" and "Deliberation Day". With its roots in an instable political climate, this crisis was also related to a specific policy problem: how to regulate party finance.

However, the Icelandic case is a sui generis due to the extent of the economic crisis as well as the degree of elite-challenging democratic innovations in its wake. The financial crisis facing Iceland in 2008 brought with it not only policy problems related to financial issues but also a substantial challenge to the political climate in terms of governmental and local government institutions lacking legitimacy. These developments spired innovative and pervasive forms of e-participation processes at the national level as well as in the city of Reykjavik. In contrast to the elements of crisis described in Sweden and Estonia, the situation in Iceland could be described as a more fundamental crisis affecting several sectors and functions in society.

Table 1. Key contexts influencing e-participation implementation

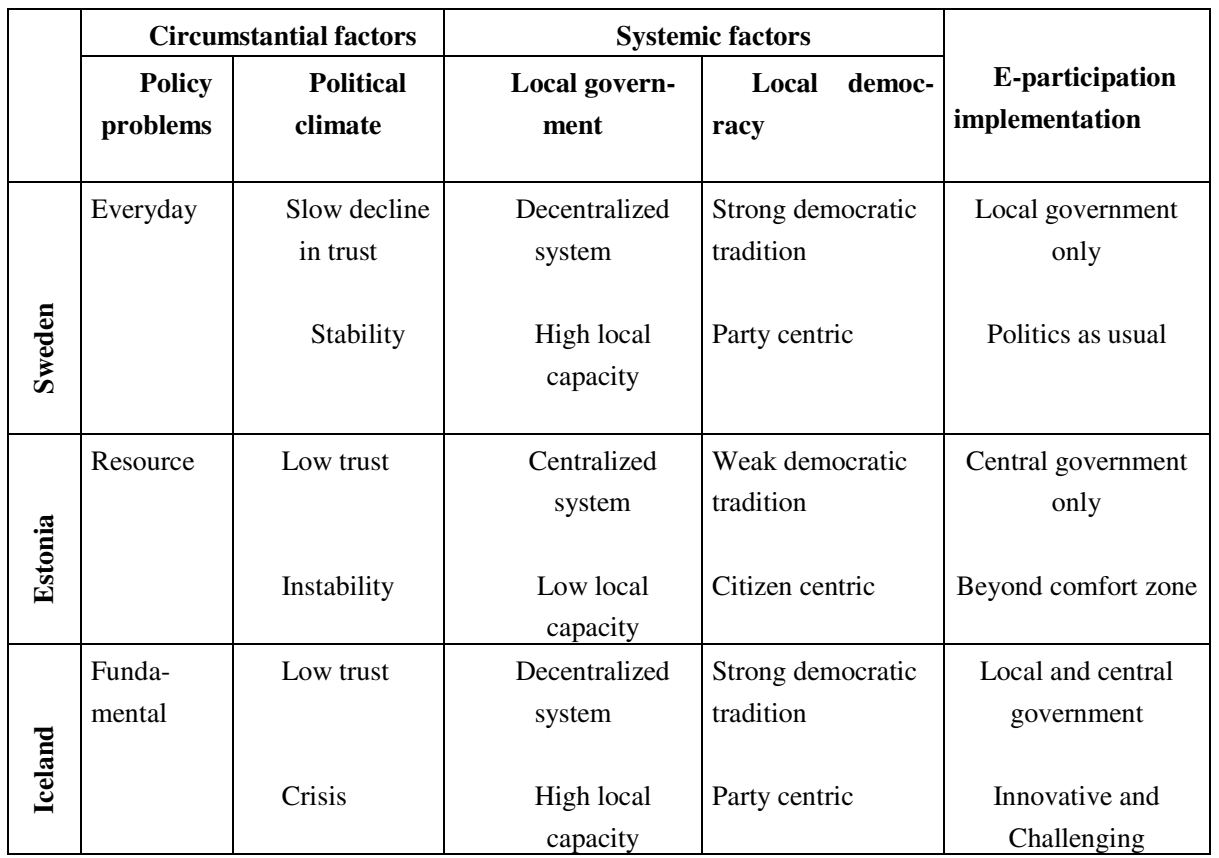


Table 1 summarizes the main differences and similarities among the cases. As has been argued above, both systemic and circumstantial factors seem to influence eparticipation implementation. When it comes to circumstantial factors, which are of particular interest in this paper, the results suggest that the lower the trust and the deeper the policy problems are, the higher the chances are for an elite-challenging implementation. An interesting common feature of the more innovative and elitechallenging initiatives are their lack of sole management by state bodies from the topdown. Instead, they have come into being from outside the state, with civil society participating in deciding the rules of the game. It would thus seem that crisis makes eparticipation more innovative by making it less government-organised and interpreted more in terms of citizen or civil-society concerns, reflecting the tension in democratic theory between models of participation promoted by incumbent power-holders and autonomous initiatives driven by self-actualizing citizens [37].

\section{Conclusions}

The crisis of representative democracy may work as a starting point for democratic renewal initiatives in many cities around the world, but these initiatives vary considerably in terms of their elite-challenging aspirations. In this article, we have argued that circumstantial factors are as important as systemic factors in order to understand why. Within this framework, it becomes just as important to distinguish between crises as to distinguish between institutions. Without both these sets of factors, the results of the comparative case study would be more difficult to understand, but empirical work on less-straightforward case studies would help to achieve a more sophisticated understanding between crisis and e-participation.

Earlier studies of e-participation have focused foremost on the influence of institutional and systemic factors on e-participation implementation while largely ignoring or overlooking crisis, a concept that has had a central position in other related fields of social scientific research interested in innovations in government and society (i.e., organizational studies and economics). The findings of this analysis encourage more research on the interplay between crisis and institutions in shaping the e-participation processes and on how different kinds, or degrees, of crisis affect e-participation implementation. [38]

\section{References}

1. Daemen, H., Schaap, L.: Renewal of Local Democracies: Puzzles, Dilemmas and Options. Springer VS, Wiesbaden (2012)

2. Smith, G.: Democratic Innovations - Designing Institutions for Citizen Participation. University Press, Cambridge (2009)

3. Fung, A.: Recipes for Public Spheres: Eight Institutional Design Choices and Their Consequences. Journal of Political Philosophy 11(3), 338-367 (2003) 
4. Åström, J., Grönlund, Å.: Online Consultations in Local Government: What works, When and Why? In: Coleman, S., Shane, P.M. (eds.) Connecting Democracy: Online Consultation and the Flow of Political Communication. MIT Press, Cambridge (2011)

5. Newton, K.: Curing the democratic malaise with democratic innovations. In: Geissel, B., Newton, K. (eds.) Evaluating Democratic Innovations: Curing the Democratic Malaise? Routledge, Oxon (2012)

6. Trevisan, F., Oates, S.: Same Recipe but different Ingredients? Challenges and Methodologies of Comparative Internet/Politics Research. Paper presented at the 2012 American Political Science Association Annual Meeting, New Orleans, LA, August 30-September 2 (2012)

7. Åström, J., Karlsson, M.: 2011. Blogging in the shadow of parties: Collectivism and individualism in the Swedish 2010 election. Paper präsentiert bei den ECPR JointSessions, 12-17. St. Gallen (April 2011)

8. John, P.: Methodologies and Research Methods in Urban Political Science. In: Baldersheim, H., Wollman, H. (eds.) The Comparative Study of Local Government and Politics: Overview and Synthesis, pp. 67-82. Budrich, Opladen (2006)

9. Wolman, H.: Comparing local government systems across countries: conceptual and methodological challenges to building a field of comparative local government studies. Environment and Planning C, Government and Policy 26, 87-103 (2008)

10. Pierre, J.: Comparative Urban Governance: Uncovering Complex Causalities. Urban Affairs Review 40(4), 446-462 (2005)

11. Dalton, R.J.: Citizenship Norms and the Expansion of Political Participation. Political Studies 56, 76-98 (2008)

12. Inglehart, R., Welzel, C.: Modernization, cultural change, and democracy: the human development sequence. Cambridge University Press, Cambridge (2005)

13. Blaug, R.: Engineering Democracy. Political Studies 50(1), 102-116 (2002)

14. Coleman, S., Blumler, J.G.: The Internet and democratic citizenship: theory, practice and policy. Cambridge University Press, Cambridge (2009)

15. Denters, B., Klok, P.-J.: Citizen Democracy and the Responsiveness of Councillors: The Effects of Democratic Institutionalisation on the Role Orientations and Role Behaviour of Councillors. Local Government Studies (2012) (Online first)

16. Bäck, H., Larsson, T.: Den Svenska politiken: Struktur, processer och resultat. Liber, Malmö (2006)

17. Fraile, M.: A comparative study of Political Knowledge in the, European Elections. Paper presented at the PIREDEU Final Conference, November 18-20, Brussels (2010)

18. Swedens Elections Authority (SEA), Electoral results 2010 (2010).

http: / /www. val.se

19. Goul Andersen, J.: Udviklingen i den politiske deltagelse i de nordiske lande. In: Esaiasson, P., Westholm, A. (eds.) Deltagandets Mekanismer: Det Politiska Engagemangets Orsaker och Konsekvenser. Liber, Malmö (2006)

20. Holmberg, S.: Down and down we go: political trust in Sweden. In: Norris, P. (ed.) Critical Citizens: Global Support for Democratic Governance. Oxford University Press, Oxford (1999)

21. Montin, S.: Mobilizing for participatory democracy? The case of democracy policy in Sweden. In: Zittel, T., Fuchs, D. (eds.) Participatory Democracy and Political Participation-Can Participatory Engineering Bring Citizens Back in? Routledge, Oxon (2007)

22. Elster, J.: Forces and mechanisms in the constitution-making process. Duke Law Journal 45, 364 (1995-1996) (retrieved: HeinOnline) 
23. Karlsson, M.: Participatory initiatives and political representation: The case of local councillors in Sweden. Local Government Studies 38(6), 795-815 (2012)

24. Åström, J.: Mot en digital demokrati? Teknik, politik och institutionell förändring. Örebro Univ., Örebro (2004)

25. Granberg, M., Åström, J.: Civic Participation and Interactive Decision-making: A Case Study. In: Amnå, E. (ed.) New Forms of Citizen Participation. Normative Implications. Nomos, Baden-Baden (2010)

26. Amnå, E.: Playing with fire? A Swedish mobilization for deliberative democracy. Journal of European Public Policy 13(4) (2006)

27. Åström, J., Granberg, M., Khakee, A.: Apple Pie-Spinach Metaphor: Shall e-Democracy make Participatory Planning More Wholesome? Planning Practice and Research 26(5), 571-586 (2011)

28. Sootla, G., Toots, A.: Report on the State of Local Democracy in Estonia. In: Soós, G. (ed.) Local Democracy in Central Europe - Reports from Bulgaria, Estonia, and Slovakia. Local Government and Public Service Reform Initiative. Open Society Institute, Budapest (2006)

29. Madise, Ü.: Elections, Political Parties, and Legislative Performance in Estonia: Institutional Choices from the Return to Independence to the Rise of E-Democracy. Tallinn University of Technology Press, Tallinn (2007)

30. Charter 12 (2012), http: / / www . harta12 . ee/eng/

31. Hovgaard, G., Eythórsson, G.T., Fellman, K.: Future Challenges to Small Municipalities The Cases of Iceland, Faroe Islands and Åland Islands, Nordregio, Stockholm, Sweden, p. 21 (2004)

32. Kristjánsson, S.: Iceland: A Parliamentary Democracy with a Semi-Presidential Constitution. In: Strøm, K., Müller, W.C., Bergman, T. (eds.) Delegation and Accountability in Parliamentary Democracies, p. 399. Oxford University Press, New York (2003)

33. Gylfason, T.: From Collapse to Constitution: The Case of Iceland. Cesifo Working Paper No. 3770 (2012b)

34. Vision of the Information Society, The Icelandic Government (October 1, 1996), http: //eng. forsaetisraduneyti.is/informationsociety/English/nr/890 (retrieved August 23, 2012)

35. Guðmundsson, H.J.: The role of public participation in creating a sustainable development policy at the local level. An example from the City of Reykjavík, Iceland. Report (For publication in: Local Environment. The International Journal of Justice and Sustainability), The City of Reykjavik, Department of Environment (2007)

36. Gylfason, T.: Constitutions: Send in the Crowds (2012a), http: / / notendur . hi . is

37. Bennet, W.L.: Changing Citizenship in the Digital Age. In: Bennet, W.L. (ed.) Civic Life Online: Learning How Digital Media Can Engage Youth. MIT Press, Cambridge (2007)

38. We gratefully acknowledge financial support from Vinnova, Nordforsk, the Icelandic Centre for Research (Rannis) and Estonian Ministry for Economic Affairs and Communication. The research presented in this article has received funding from Citizen-Centric eGovernment Services Programme 